\title{
Motivations for attracting customers and their intention to participate in tourism events in Ho Chi Minh City
}

\author{
Trinh Thuy Anh ${ }^{1 *}$, Tran Kiem Viet Thang ${ }^{1}$ \\ ${ }^{1}$ Ho Chi Minh City Open University, Vietnam \\ *Corresponding author: thuyanh@ou.edu.vn
}

\begin{tabular}{ll}
\hline \multicolumn{1}{c}{ ARTICLE INFO } & \multicolumn{1}{c}{ ABSTRACT } \\
\hline $\begin{array}{l}\text { DOI: } 10.46223 / \text { HCMCOUJS. } \\
\text { econ.en.10.1.218.2020 }\end{array}$ & $\begin{array}{l}\text { The study examines the impact of factors influencing } \\
\text { customers intention to attend a tourism event, by considering } \\
\text { the motivation to attract customers to such an event. The authors } \\
\text { collected } 230 \text { interview samples from different subjects, then } \\
\text { conducted a quantitative method through factor, correlation, and } \\
\text { Received: March } 13^{\text {th }}, 2020\end{array}$ \\
$\begin{array}{l}\text { Revised: April } 8^{\text {th }}, 2020 \\
\text { Accepted: April } 20^{\text {th }}, 2020\end{array}$ & $\begin{array}{l}\text { attract customers to tourism events has a great influence on their } \\
\text { participating intention. In particular, factors affecting the } \\
\text { motivation to take part in the event include influence group, } \\
\text { communications, convenience, and content. The analysis results } \\
\text { give several suggestions for event organizers to be able to gain } \\
\text { more customer engagement. }\end{array}$ \\
$\begin{array}{l}\text { tourism events, intention to } \\
\text { participate, motivations to attract } \\
\text { customers }\end{array}$ &
\end{tabular}

\section{Introduction}

Vietnam tourism is considered a spearhead economic sector. With the diverse and abundant tourism potential of the country, Vietnam's tourism has grown tremendously in recent years (Phuong Anh, 2019). According to the General Statistics Office (Statistics, 2019a), the number of international visitors to Vietnam in 2019 was 18 million, an increase of $16.2 \%$ compared to 2018 . In the period from 2015-2019, the International visitors to Vietnam have increased 2.3 times from 7.9 million to 18 million, the average growth rate is $22.7 \%$ per year. The number of domestic tourists in 2018 reached 80 million, reaching an average growth rate of 10\% per year (Statistics, $2019 b)$. Vietnam is consistently among the countries with the fastest tourist growth rates in the world. In 2019, Vietnam tourism receives the award of the world's leading heritage destination by the World Travel Awards, the best golf destination in the world by the World Golf Awards. The World Travel Awards also honors Vietnam as Asia's Leading Destination for two consecutive years 2018-2019, Asia's leading cultural destination 2019, Asia's leading culinary destination 2019 (Truyen Phuong, 2019). Among the typical events of the country, tourism events are evaluated to be outstanding in recent years (Specialists, 2019).

Tourism events also bring benefits to organizations but also contribute to marketing and promoting the culture and unique beauty of each locality, such as Vietnam hosting the ASEAN Tourism Forum this year 2019, Vietnam International Tourism Fair 2019 in Hanoi, Opening Ceremony of National Tourism Year 2019 and Nha Trang Sea Festival - Khanh Hoa 2019, the United Nations Great Buddha Ceremony, Da Nang international flowers Festival 2019 (Hu Truc, 2019). In Ho Chi Minh City, many tourism events such as Nguyen Hue Flower Street and 
Vietnamese ao dai event. Understanding the positive benefits tourism events can bring, more and more businesses have begun to participate in organizing the events. The Vietnam National Administration of Tourism believes that the solution for tourism development is associated with events in Vietnam (Thu Thuy, 2019).

The number of attendants is one of the factors contributing to the success of organizing an event. The problem for businesses is what is needed to attract customers to the event and what factors will influence the participation of people. The study of the influential factors of attraction to the event is very important and urgent to achieve public relations effect in event marketing.

Currently, in Vietnam, there are many studies on factors affecting customer intentions. However, there are still limited studies on customer intention concerning the motivation to attract them to the event, especially in the field of tourism. Therefore, this study aims to understand the factors affecting the motivation to attract customers to tourism events and to find out the impact of that on customers' intentions when participating in the events.

The study uses qualitative methods in combination with quantitative analysis to measure the factors affecting customer motivation and their intention to attend tourism events.

The results of this study contribute to the completion of a scale system that shows factors motivating customers to participate in tourism events. This study also serves as a reference and suggests some solutions for tour organizers to better attract customers to their events.

\section{Literature review}

\subsection{Theoretical framework}

This study was conducted based on two foundations, namely consumer behavior theory and motivation theory.

According to Maslow's theory of motivation (1943), people need to eat, to feel safe, to socialize and make friends, to be respected, and to express themselves. Attending a tourism event can help meet the needs of eating, socializing, being respected, and expressing oneself. Alderfer (1969) asserted that people need to satisfy all three needs: existence, relatedness, and growth. Attending a tourism event helps to meet all 3 of these needs. McCleland $(1953,1969)$ also emphasized the need for achievement (including physiological and safety needs), affiliation, and power. We can see that participating in tourism events satisfies the needs of eating and connection. In addition, Nohria and Groysberg (2008) also mentioned the need for learning, which is also one of the objectives of tourists, so it is also considered in this study.

According to the consumer behavior theory of Bennett (1989), there is a dynamic interaction among influencing factors, perceptions, behaviors, and the environment, and through that will change people's lives. Besides, according to Michael (2013), consumer behavior is a process that allows an individual or a group of people to choose, to purchase, to use, or to dismiss a product, service, an existing thought, or an experience, to satisfy their needs or aspirations. According to Kotler (2014), the recognition of needs to the evaluation of buying options to postpurchasing is a long process, and they are related to each other.

Tourism events are meant to create an environment and opportunities for interaction between organizations and businesses with the public to bring out attention to the products and services. The result is to help increase brand awareness and sales for the company. 
According to Bui and Mai (2012), Le and Tran (2014), tourism events are quite popular nowadays in Vietnam to promote travel activities, attract tourists, and promote culture, cuisine, and customs of the local people. The types of tourism events are very diverse and infused with local nuances to become the unique feature of one culture.

\subsection{Previous studies}

Rachael and Douglas (2001) found that the specific factors of motivation are diversified between food and beverage festivals, an air show, and a country and music festival.

Crompton and McKay (1997) mentioned push-pull factors to identify the motives of visitors to go to the festival event. They found that six motive domains emerged: cultural exploration, novelty/regression, recover equilibrium, known group socialization, external interaction/socialization, and gregariousness. Thompson and Schofield (2009) also found five stable motivation segments to visitors attending the cultural festival, these were: multipurpose seekers; indifferent; culture and sport seekers; togetherness, socialization, and sports seekers; and socialization and local event seekers. Denaux, Denaux, and Yalcin (2011) found that time factors, fan interest, city characteristics, team's performance, and fan's attendance behavior have strong influences on the baseball game attendance. Hudson (2010) mentioned the factors that influence the decision to attend two different types of events, which are sports and art entertainment events of Cal Poly students. Three factors influence a participant's decision to take part in any art and entertainment event, namely society, economic situation, and motivation of participants. The two factors that influence the decision to participate in a sport event are team appointments and social rewards. Therefore, the influence group could be seen as an impact on the motivations of participating in tourism events.

Martensen and Grønholdt (2008) found that marketing communication and brand were very important to create the effect of the event. Communication and its effect could be seen as a significant influence on the motivation of participating in events.

To generalize the relationship between factors of destination supply and tourism demand, Vengesayi, Mavondo, and Reisinger (2013) proposed the TDCA (Tourism Destination Competitiveness And Attractiveness) model, in which elements of resources, activities of the destination, the interaction with the tour experience and complementary services, PR and advertising strategies are the basic factors that make a destination attractive. For example, factors of nature, history, culture, event and entertainment activities, etc. of the destination, are all attracting customers to participate in tourism events. From this research, communication, location, and content could be seen as important factors to impact visitor attendance.

Bauer, Law, Tse, and Weber (2008) surveyed to identify the reason to push people to join a business event. Business benefits and networking opportunities were the two main reasons that attract people to join. This research also ensures that communication and content are the right factors to attract people to the event.

Aziz (2002) found that visitor's attitude is the main factor affect to visitor's attendance. Besides, previous experience of people, location, convenience, and time of trip also affected visitor's decisions of attendance. Bui and Mai (2012) found that weather, location, convenience, and event content will motivate customers to attend. Aaron (2013) stated that the time of the event, the weather, and content were the main factors affecting students to attend a sport event. Nguyen, Tran, and Le (2017) showed that weather and location are the two main factors affecting the 
attraction of domestic tourism. From these studies, location, convenience, timing, and weather and then content could be considered as factors affecting people to attend the event.

\section{Research model and methods}

\subsection{Research model}

Based on the above studies, we know that many factors are affecting the attraction of customers attending an event in general and a tourism event. From there, the authors propose a research model in Figure 1.

Influence groups are factors that can influence the thoughts, perceptions, assessments, behaviors, or desires of a particular person or group of people. (Denaux et al., 2011; Hudson, 2010; Rachael \& Douglas, 2001; Thompson \& Schofield, 2009). The authors hypothesize:

H1: The influence group has a positive impact on the motivation to participate in tourism events

Communication is a factor that helps increase confidence in the event and increase participation decisions (Bauer et al., 2008). Media publications of events such as advert flags, banners, leaflets, and event brochures will increase the confidence of customers and motivate their attending to the event because this proves the popularity and scale of the event (Vengesayi et al., 2013). Crompton and McKay (1997), Martensen and Grønholdt (2008) also accepted the role of communication in attracting people to join the event. The authors hypothesize:

H2: Strong communication has a positive impact on the participating motivation in tourism events

Currently, the number of vehicles is increasing, social evils can appear at events that make tourists reluctant to participate (Bui \& Mai, 2012). Therefore, location is an important determinant of participation in tourist events (Aziz, 2002; Aaron, 2013; Bauer et al., 2006). The authors hypothesize:

H3: A favorable location has a positive impact on the participating motivation in a tourism event

Tourism events are meant to be well organized, but if they are not convenient for customers, this is difficult to attract customers' attention (Aaron, 2013; Aziz, 2002; Bui \& Mai, 2012; Nguyen et al., 2017). From there comes the hypothesis:

H4: Convenience has a positive impact on the motivation to participate in tourism events

Weather and timing affect the decision to participate in sports and entertainment events. Not only that, customers are distracted by many activities of the day, and weather can also hinder the attraction of customers attending the event (Aziz, 2002; Bui \& Mai, 2012; Denaux et al., 2011; Nguyen et al., 2017). From there comes the hypothesis:

H5: The appropriate time and weather have a positive impact on the motivation to participate in the tourism event

The content of an event is the soul of it, so it can either make the event attractive or boring (Aaron, 2013; Bauer et al., 2006; Bui \& Mai, 2012; Crompton \& McKay, 1997). From that comes the hypothesis:

H6: Appealing content has a positive impact on the motivation to participate in tourism events 
Maslow (1943) explained that human motivation is organized in a hierarchical order, from basic physiological and safety needs to more advanced needs of communication, esteem, and selfactualization needs. Bauer et al. (2006) found that if the last events satisfied customer's needs then they would have more motivation to attend the next event. According to Hudson (2010), Aaron (2013), motivational factors influencing a decision to attend an event include stress reduction, health improvement, and stimulation and entertainment seeking. Bui and Mai (2012) said that enjoying the culinary delights is also an incentive for customers to enjoy the event. The authors hypothesize:

H7: The motivation for event participation has a positive impact on the intention to attend that event

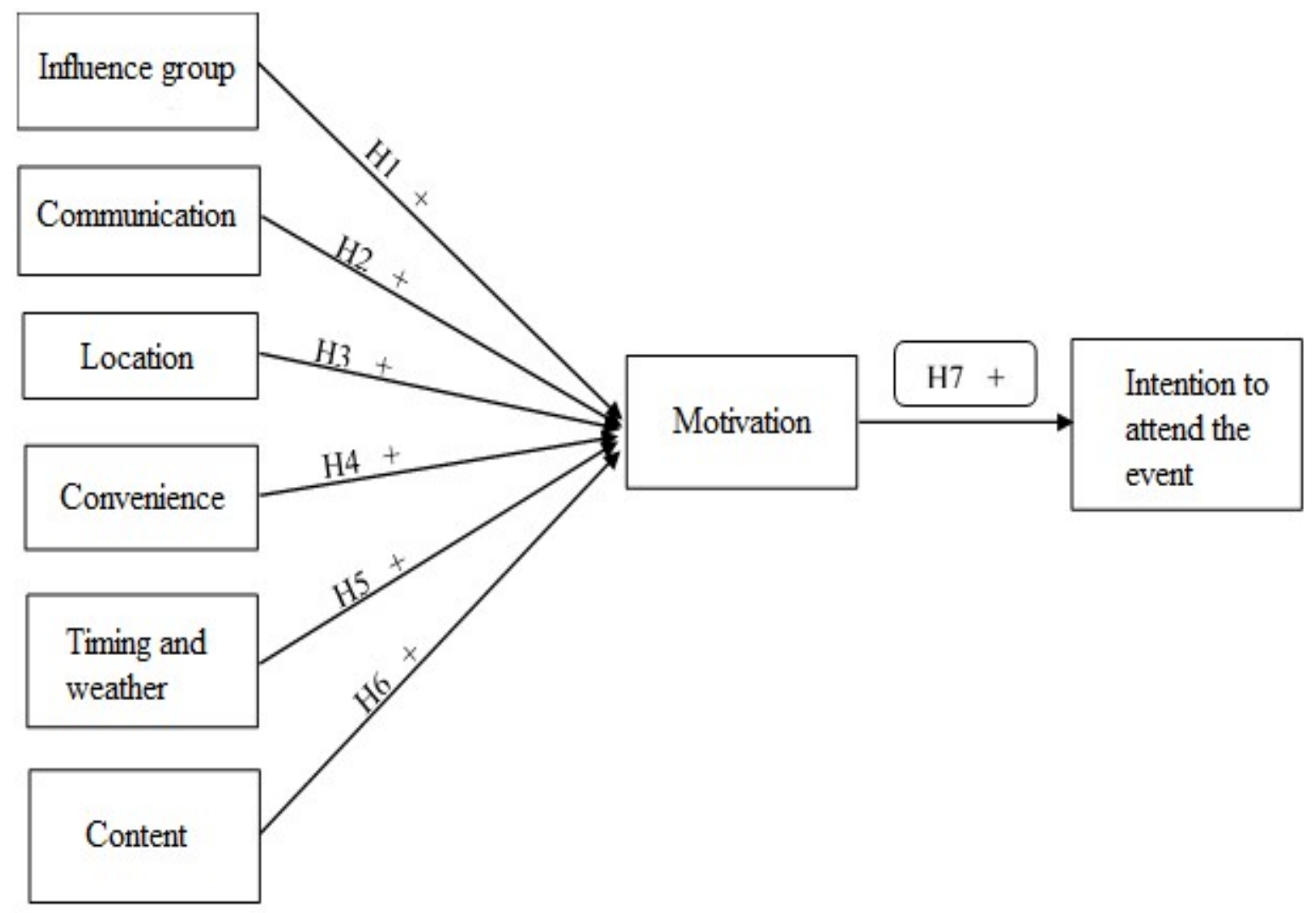

Figure 1. Research model

\section{The scale:}

All scales of concepts in the research are multivariate scales. Likert's 5-point scale (1: Strongly disagree; 2: Disagree; 3: Neutral; 4: Agree, and 5: Strongly agree) is used to measure observed variables. The scales were formed based on previous studies and experts' consultation (Table 1). 


\section{Table 1}

Summary of scales

\begin{tabular}{|c|c|c|}
\hline Factor & Observed variables & Citation \\
\hline \multirow{4}{*}{$\begin{array}{l}\text { Influence group } \\
\text { factor }\end{array}$} & AH1: Tourism events have VIP guests & $\begin{array}{l}\text { Crompton and McKay (1997), } \\
\text { Thompson and Schofield (2009) }\end{array}$ \\
\hline & $\begin{array}{l}\text { AH2: Tourism events have well-known } \\
\text { sponsors and organizations }\end{array}$ & $\begin{array}{l}\text { Denaux et al. (2011), Thompson and } \\
\text { Schofield (2009) }\end{array}$ \\
\hline & $\begin{array}{l}\text { AH3: Tourism events are organized on a large } \\
\text { scale }\end{array}$ & Thompson and Schofield (2009) \\
\hline & $\begin{array}{l}\text { AH4: You want to experience tourism events } \\
\text { with friends and family }\end{array}$ & Denaux et al. (2011) \\
\hline \multirow{5}{*}{$\begin{array}{l}\text { Communication } \\
\text { factor }\end{array}$} & TT1: Tourism events are widely advertised & $\begin{array}{l}\text { Martensen and Grønholdt (2008), } \\
\text { Vengesayi et al. (2013) }\end{array}$ \\
\hline & $\begin{array}{l}\text { TT2: Sponsors and co-organizers are } \\
\text { frequently mentioned in the event }\end{array}$ & Bauer et al. (2006) \\
\hline & $\begin{array}{l}\text { TT3: You have easy access to buy and receive } \\
\text { tickets }\end{array}$ & Martensen and Grønholdt (2008) \\
\hline & $\begin{array}{l}\text { TT4: Messages and images of tourism events } \\
\text { are meaningful and attractive }\end{array}$ & $\begin{array}{l}\text { Martensen and Grønholdt (2008), } \\
\text { Vengesayi et al. (2013) }\end{array}$ \\
\hline & $\begin{array}{l}\text { TT5: Tourism events are advertised on } \\
\text { reliable channels }\end{array}$ & Vengesayi et al. (2013) \\
\hline \multirow{4}{*}{ Location } & $\begin{array}{l}\text { DD1: Tourism event locations are } \\
\text { conveniently matching with your travelling }\end{array}$ & Aziz (2002), Bui and Mai (2012) \\
\hline & $\begin{array}{l}\text { DD2: Tourism events are held in the city } \\
\text { centers }\end{array}$ & Aziz (2002), Aaron (2013) \\
\hline & $\begin{array}{l}\text { DD3: Tourism events are held near where you } \\
\text { live and work }\end{array}$ & Nguyen et al. (2017) \\
\hline & $\begin{array}{l}\text { DD4: Tourism events' security is generally } \\
\text { stable }\end{array}$ & Bui and Mai (2012) \\
\hline \multirow{6}{*}{ Convenience } & $\begin{array}{l}\text { TH1: Tourism events have or are near parking } \\
\text { lots }\end{array}$ & Bui and Mai (2012) \\
\hline & $\begin{array}{l}\text { TH2: Tourism events are not too crowded, } \\
\text { cramped, and noisy }\end{array}$ & Aziz (2002), Bui and Mai (2012) \\
\hline & $\begin{array}{l}\text { TH3: Tourism events have tables and chairs } \\
\text { for participants to sit and rest }\end{array}$ & Bui and Mai (2012) \\
\hline & $\begin{array}{l}\text { TH4: Tourism events have delicious food and } \\
\text { reasonable price }\end{array}$ & Nguyen et al. (2017) \\
\hline & $\begin{array}{l}\text { TH5: Tourism events have children playing or } \\
\text { babysitting sections }\end{array}$ & Qualitative survey \\
\hline & TH6: The event's facilities are generally good & Nguyen et al. (2017) \\
\hline Time, weather & $\begin{array}{l}\text { TG1: Time to organize tourism events is } \\
\text { suitable for you to attend }\end{array}$ & $\begin{array}{l}\text { Aziz (2002), Denaux et al. (2011), } \\
\text { Aaron (2013) }\end{array}$ \\
\hline
\end{tabular}




\begin{tabular}{|c|c|c|}
\hline Factor & Observed variables & Citation \\
\hline & TG2: Tourism events are held on weekends & Denaux et al. (2011), Aaron (2013) \\
\hline & $\begin{array}{l}\text { TG3: Tourism events are held at suitable } \\
\text { weather conditions }\end{array}$ & $\begin{array}{l}\text { Aaron (2013), Bui and Mai (2012), } \\
\text { Nguyen et al. (2017) }\end{array}$ \\
\hline \multirow{4}{*}{$\begin{array}{l}\text { Tourism event } \\
\text { content }\end{array}$} & $\begin{array}{l}\text { ND1: Tourism events have attractive and } \\
\text { interesting content }\end{array}$ & Aziz (2002), Bui and Mai (2012), \\
\hline & $\begin{array}{l}\text { ND2: Tourism events have content that is } \\
\text { attracting attention at present }\end{array}$ & $\begin{array}{l}\text { Crompton and McKay (1997), } \\
\text { Aaron (2013) }\end{array}$ \\
\hline & $\begin{array}{l}\text { ND3: Tourism events have new and trend- } \\
\text { catching content }\end{array}$ & Aaron (2013) \\
\hline & $\begin{array}{l}\text { ND4: Tourism events have suitable content } \\
\text { for participants }\end{array}$ & $\begin{array}{l}\text { Crompton and McKay (1997), } \\
\text { Aaron (2013) }\end{array}$ \\
\hline \multirow{5}{*}{$\begin{array}{l}\text { Motivation to } \\
\text { attend tourism } \\
\text { events }\end{array}$} & $\begin{array}{l}\text { DC1: You are broadened your vision and } \\
\text { understanding when attending tourism events }\end{array}$ & Aziz (2002), Hudson (2010) \\
\hline & $\begin{array}{l}\text { DC2: You search and connect to the network } \\
\text { when attending tourism events }\end{array}$ & Thompson and Schofield (2009) \\
\hline & $\begin{array}{l}\text { DC3: You experience the new and unique } \\
\text { shows when attending tourism events }\end{array}$ & $\begin{array}{l}\text { Thompson and Schofield (2009), } \\
\text { Hudson (2010 }\end{array}$ \\
\hline & $\begin{array}{l}\text { DC4: You receive valuable gifts or experience } \\
\text { free travel when attending tourism events }\end{array}$ & Hudson (2010) \\
\hline & $\begin{array}{l}\text { DC5: You enjoy culinary delights at tourism } \\
\text { events }\end{array}$ & Bui and Mai (2012) \\
\hline \multirow{6}{*}{$\begin{array}{l}\text { Intention to } \\
\text { attend tourism } \\
\text { events }\end{array}$} & $\begin{array}{l}\text { YD1: You attend tourism events whenever } \\
\text { you can }\end{array}$ & $\begin{array}{l}\text { Denaux et at. (2011), Kim and } \\
\text { Malek (2017) }\end{array}$ \\
\hline & $\begin{array}{l}\text { YD2: You will invite your friends and } \\
\text { relatives to attend tourism events }\end{array}$ & $\begin{array}{l}\text { Hudson (2010), Bui and Mai (2012), } \\
\text { Aaron (2013), Kim and Malek } \\
(2017)\end{array}$ \\
\hline & $\begin{array}{l}\text { YD3: You will attend tourism events in the } \\
\text { future }\end{array}$ & $\begin{array}{l}\text { Denaux et al. (2011), Vengesayi et } \\
\text { al. (2013) }\end{array}$ \\
\hline & $\begin{array}{l}\text { YD4: You will attend tourism events in the } \\
\text { next } 6 \text { months }\end{array}$ & $\begin{array}{l}\text { Denaux et al. (2011), Bui and Mai } \\
(2012)\end{array}$ \\
\hline & $\begin{array}{l}\text { YD5: Sometimes you will attend tourism } \\
\text { events }\end{array}$ & Kim and Malek (2017) \\
\hline & $\begin{array}{l}\text { YD6: You consider attending future tourism } \\
\text { events }\end{array}$ & Kim and Malek (2017) \\
\hline
\end{tabular}

Source: The research's data analysis

\subsection{Research methods}

The authors conduct this research to identify factors affecting the attraction of customers to tourism events through qualitative and quantitative research methods.

Phase 1: Conduct qualitative research through in-depth interviews. In-depth interviews are used to understand issues in depth to gather information. The authors conduct qualitative research through in-depth interviews with 10 people aged 18 and over, living in Ho Chi Minh City who 
have participated in tourism events. This study aims to collect opinions and objective factors and evaluate the content and form of statements in the scale to complete the official scale used in quantitative research. The most important task in this phase is to assess whether the respondent understands the questions correctly, thus making the official questionnaire available.

Phase 2: Quantitative preliminary research was conducted with a sample of 240. After the authors screened the data, there was 231, then data analysis was done using SPSS software and regression analysis to test the scale and given theories as well as the proposed research model. The post-processing data will be analyzed to bring out the factors that affect the attraction of customers to attend tourism events.

Following Anderson and Gerbing's (1988) suggestion, a two-step analytical approach was adopted. The adequacy of our measurement model was first tested by conducting CFA using AMOS 18. Multiple-regression was then performed to estimate the impact of hypothesized independent constructs on the dependent ones. As we only aimed to test the significance of the hypothesized relationships, regression was a parsimonious fit for our choice to test the model. To test the adequacy of our model, multiple model fit indices were reported as generally suggested by scholars (Browne \& Cudeck, 1993) including the chi-square goodness-of-fit to degrees of freedom ratio (x 2/df), the root mean square error of approximation (RMSEA), the standardised root mean square residual (SRMR), the Tucker-Lewis coefficient (TLI) and the comparative fit index (CFI). The following criteria of goodness-of-fit indices were used to assess the model fit: the $\mathrm{x} 2 / \mathrm{df}$ ratio is recommended to be less than 5; RMSEA acceptable up to 0.08; SRMR values no higher than 0.10 and values above 0.90 for TLI and CFI (Browne \& Cudeck, 1993).

\section{Results and discussion}

\section{Reliability testing}

The scales were tested for reliability using Cronbach's Alpha tool to eliminate observed variables or failed scales. If the observed variables have an item-total correlation coefficient greater than 0.5 , they will meet the criteria and the scale standard chosen in Cronbach's Alpha is 0.6 or higher.

\section{Table 2}

Cronbach's Alpha result

\begin{tabular}{|c|c|c|c|c|}
\hline Element & $\begin{array}{c}\text { Number of observed } \\
\text { variables }\end{array}$ & $\begin{array}{c}\text { Cronbach' } \\
\text { s Alpha }\end{array}$ & $\begin{array}{c}\text { Total extracted } \\
\text { variance }\end{array}$ & Evaluation \\
\hline Influence group & 4 & 0.871 & \multirow{6}{*}{$70.623 \%$} & \multirow{8}{*}{ Qualified } \\
\hline Communication & 5 & 0.764 & & \\
\hline Location & 4 & 0.878 & & \\
\hline Convenience & 6 & 0.840 & & \\
\hline Timing and weather & 3 & 0.865 & & \\
\hline Content & 4 & 0.737 & & \\
\hline Motivation & 5 & 0.784 & $70.64 \%$ & \\
\hline Intention to attend the event & 6 & 0.802 & $64.98 \%$ & \\
\hline
\end{tabular}

Source: Data analysis result of the research 
The first-factor analysis showed that all 22 observed variables expressed through 6 independent variables with Eigenvalue values $>1$ with a total extracted variance of $70.64 \%$. Varimax rotation method is selected. New variables with a loading factor of $>0.5$ are used to explain the factor.

In the first result, we remove the variables TH2, TH6, AH2, TT1, ND1, AH5. These variables have loading factors $<0.5$. The second-factor analysis for Eigenvalue is $>1$ with total extracted variance of $70.66 \%$ (guaranteed $>50 \%$ ), but there is a change of observed variable groups in independent variables. Specifically, in the second-factor analysis table, we have the following groups:

- Group 1 include: TH1, TH3, TH4, TH5, TT5, TT1 of the convenience scale; and two variables TT5 and TT1 of the communication scale. These factors have a close relationship and are named "the convenience and popularity of tourism events";

- Group 2 consists of 4 variables DD3, DD4, DD1, DD2 (on the scale of location). The group was still named "Tourism Event venue";

- Group 3: consists of 3 variables AH1, AH3, AH4 (on the scale of the influence group). The group still holds the name "Influence group";

- Group 4: consists of 3 variables TG1, TG2, TG3 (on the scale of time and weather). The group still holds the name "Time and weather at tourism events";

- Group 5: consists of 3 variables TT2, TT4, TT3 (of the communication scale). The group still holds the name "Media of tourism events";

- Group 6: consists of 3 variables ND2, ND2, ND3 (on the content scale). The group still holds the name "Content of tourism events".

The variables that are excluded from the model are TH2 (Tourism events are not too crowded, cramped, and noisy), TH6 (The event's facilities are generally good), AH2 (Tourism events have well-known sponsors and organizations), TT1 (Tourism events are widely advertised), ND1 (Tourism events have attractive and interesting content). After discussing with the experts, the authors eliminate these variables. This is appropriate because the tourism event is always noisy and crowded and people attending the event do not care whether it is busy or not. Similarly, attendants often come to gather information rather than entertaining, so the event facilities are not of great interest to them. Regarding the content of the event, due to the specific nature of a tourism event aiming at promoting local tourism, it is not necessary to be associated with outstanding socio-economic issues in recent times.

\section{Table 3}

Descriptive and factor analysis results

\begin{tabular}{|c|c|c|c|c|}
\hline \multirow{2}{*}{ Factors } & $\begin{array}{c}\text { Observed } \\
\text { variables }\end{array}$ & Factor loading & Medium & $\begin{array}{c}\text { Standard } \\
\text { deviation }\end{array}$ \\
\hline \multirow{4}{*}{$\begin{array}{c}\text { Convenience and popularity } \\
\text { of tourism events }\end{array}$} & TH1 & 0.783 & 4.00 & 0.846 \\
\cline { 2 - 5 } & TH3 & 0.783 & 3.91 & 0.887 \\
\cline { 2 - 5 } & TH4 & 0.796 & 4.00 & 0.964 \\
\cline { 2 - 5 } & TH5 & 0.826 & 3.72 & 0.867 \\
\cline { 2 - 5 } & TT5 & 0.758 & 4.02 & 0.665 \\
\cline { 2 - 5 } & TT1 & 0.764 & 4.00 & 0.720 \\
\hline
\end{tabular}




\begin{tabular}{|c|c|c|c|c|}
\hline \multirow{2}{*}{ Factors } & $\begin{array}{c}\text { Observed } \\
\text { variables }\end{array}$ & Factor loading & Medium & $\begin{array}{c}\text { Standard } \\
\text { deviation }\end{array}$ \\
\hline \multirow{3}{*}{ Tourism event venue } & DD1 & 0.837 & 3.89 & 0.774 \\
\cline { 2 - 5 } & DD2 & 0.876 & 3.80 & 0.850 \\
\cline { 2 - 5 } & DD3 & 0.816 & 3.75 & 0.860 \\
\cline { 2 - 5 } & DD4 & 0.844 & 3.82 & 0.840 \\
\hline \multirow{3}{*}{ Influence group } & AH1 & 0.755 & 3.93 & 0.758 \\
\cline { 2 - 5 } & AH3 & 0.808 & 3.90 & 0.784 \\
\cline { 2 - 5 } & AH4 & 0.807 & 4.00 & 0.879 \\
\hline \multirow{3}{*}{ Time and weather } & TG1 & 0.796 & 4.00 & 0.667 \\
\cline { 2 - 5 } & TG2 & 0.860 & 4.02 & 0.677 \\
\cline { 2 - 5 } & TG3 & 0.799 & 4.00 & 0.712 \\
\hline \multirow{3}{*}{ Media } & TT2 & 0.841 & 3.95 & 0.688 \\
\cline { 2 - 5 } & TT3 & 0.783 & 3.73 & 0.860 \\
\cline { 2 - 5 } & TT4 & 0.796 & 4.02 & 0.664 \\
\hline \multirow{3}{*}{ Content } & ND1 & 0.683 & 4.07 & 0.613 \\
\cline { 2 - 5 } & ND2 & 0.733 & 3.92 & 0.649 \\
\cline { 2 - 5 } & ND3 & 0.681 & 3.99 & 0.727 \\
\hline
\end{tabular}

Source: Data analysis result of the research

The scale of motivation to participate in a tourism event: To qualify for factor analysis, the authors carry out KMO and Bartlett's Test. KMO value, in this case, is 0.627 and is statistically significant (significance level $=0.000$ ). Hence, these 5 variables are correlated with each other, perfectly suitable for factor analysis. By using EFA analysis technique with the Principal Component extraction method combined with Varimax rotation, the authors extracted a single factor with an Eigenvalue of 2,599 and the total extraction variance was $64.98 \%$ (guaranteed $\geq$ $50 \%$ ). On the other hand, the load factor of observed variables is highly ranged from 0.681 to 0.886 , so all variables are accepted on the scale.

The scale of intention to participate in tourism events: KMO value is 0.808 and is statistically significant (significance level $=0.000$ ), which shows that these 4 variables are correlated with each other and perfectly suitable for factor analysis. By using EFA analysis, the authors extracted a single factor with an Eigenvalue of 3,069 and the total variance extracted was $51.142 \%$ satisfying the condition. The load factor of the observed variables is highly ranged from 0.651 to 0.802 , so all variables are accepted on the scale.

The results of Cronbach's alpha reliability test and factor analysis (EFA) have restructured 6 factors affecting the participating motivation in tourism events, including influence group, media, location, and convenience and popularity of tourism events, time and weather, and content.

The results of the CFA indicated that our hypothesized six-factor measurement model showed acceptable fit with the data: $\mathrm{x} / \mathrm{df}=1.43, \mathrm{RMSEA}=.0062, \mathrm{SRMR}=0.067, \mathrm{TLI}=0.91$ and $\mathrm{CFI}=0.9$. Standardized coefficients from items to factors ranged from 0.47 to 0.78 . All the regression weights were significant ( $\mathrm{p} \& 1 \mathrm{lt} ; 0.001$ ), indicating the posited relationships among indicators and constructs and thus the convergent validity, supporting the distinctiveness of the constructs in our study (Hair, Anderson, Tatham, \& Black, 1998). 
Table 4

Assessing the model's suitability

\begin{tabular}{|c|c|c|c|c|}
\hline Model & $\mathbf{R}$ & $\mathbf{R}^{\mathbf{2}}$ & Corrected $\mathbf{R}^{\mathbf{2}}$ & Standard error of $\mathbf{R}^{\mathbf{2}}$ \\
\hline 1 & $.737^{\mathrm{a}}$ & 0.542 & 540 & 0.355 \\
\hline
\end{tabular}

Source: Data analysis result of the research

After analyzing factor and correlation among variables, the authors analyzed two regression models:

Regression model 1: Regression analysis of motivation to participate in tourism events (DC) variable based on 6 independent variables. The given model is suitable, coefficient $R$ is 0.737 and the adjusted coefficient R2 is 0.542 ; this means the model coverage is $54 \%$ (Table 5).

Regression analysis results are presented in Table 5. Hence, there are 4 factors with Sig $=$ $0.000<0.05$ satisfactory with the model, only 2 variables DD and TG have Sig 0.081 and $0.747>$ 0.05 respectively, are not statistically significant, so these two factors will be removed. The beta of these variables is positive, indicating that the relationship of the independent variable on the dependent variable is in the same direction. According to the analysis results, the content has the highest influence on the motivation to participate in the events (Beta $=0.271$ ). Next is the communication factor $($ Beta $=0.242)$ and the convenience and popularity of tourism events (Beta $=0.209)$. The influence group factor $($ Beta $=0.184$ ) has less impact on customer motivation to participate. The two factors of location, time, and weather do not affect the motivation of those participating in tourism events.

Considering VIF (Variance Inflation Factor) to check the linearity multiplication, we find that the VIF of most factors is $<2$, so multi-linearity does not occur.

\section{Table 5}

Regression model 1

\begin{tabular}{|c|c|c|c|c|c|c|c|c|}
\hline \multicolumn{9}{|c|}{ Coefficients $^{\mathrm{a}}$} \\
\hline & \multirow[t]{2}{*}{ Model } & \multicolumn{2}{|c|}{$\begin{array}{l}\text { Unstandardized } \\
\text { Coefficients }\end{array}$} & \multirow{2}{*}{$\begin{array}{c}\begin{array}{c}\text { Standardized } \\
\text { Coefficients }\end{array} \\
\text { Beta }\end{array}$} & \multirow[t]{2}{*}{$\mathbf{t}$} & \multirow[t]{2}{*}{ Sig. } & \multicolumn{2}{|c|}{$\begin{array}{l}\text { Collinearity } \\
\text { Statistics }\end{array}$} \\
\hline & & B & Std. Error & & & & Tolerance & VIF \\
\hline \multirow{7}{*}{1} & (Constant) & -.074 & .346 & & -.213 & .832 & & \\
\hline & $\mathrm{TH}$ & .209 & .059 & .200 & 3.529 & .001 & .817 & 1.223 \\
\hline & DD & .100 & .057 & .102 & 1.755 & .081 & .769 & 1.300 \\
\hline & $\mathrm{AH}$ & .184 & .041 & .233 & 4.437 & .000 & .948 & 1.055 \\
\hline & $\mathrm{TT}$ & .242 & .057 & .242 & 4.226 & .000 & .801 & 1.248 \\
\hline & TG & .015 & .046 & .017 & .323 & .747 & .905 & 1.104 \\
\hline & ND & .271 & .052 & .293 & 5.23 & .000 & .843 & 1.187 \\
\hline
\end{tabular}

Source: Data analysis result of the research 
The regression equation 1 has the following form:

$$
\mathrm{DC}=-0.074+0.209 \mathrm{TH}+0.184 \mathrm{AH}+0.242 \mathrm{TT}+0.271 \mathrm{ND}
$$

Regression Model 2: Regression analysis of variable Intention (YD) to participate in the event based on motivation variable (DC). Table 6 presents the results of the regression model 2 analysis.

Table 6

Regression model 2

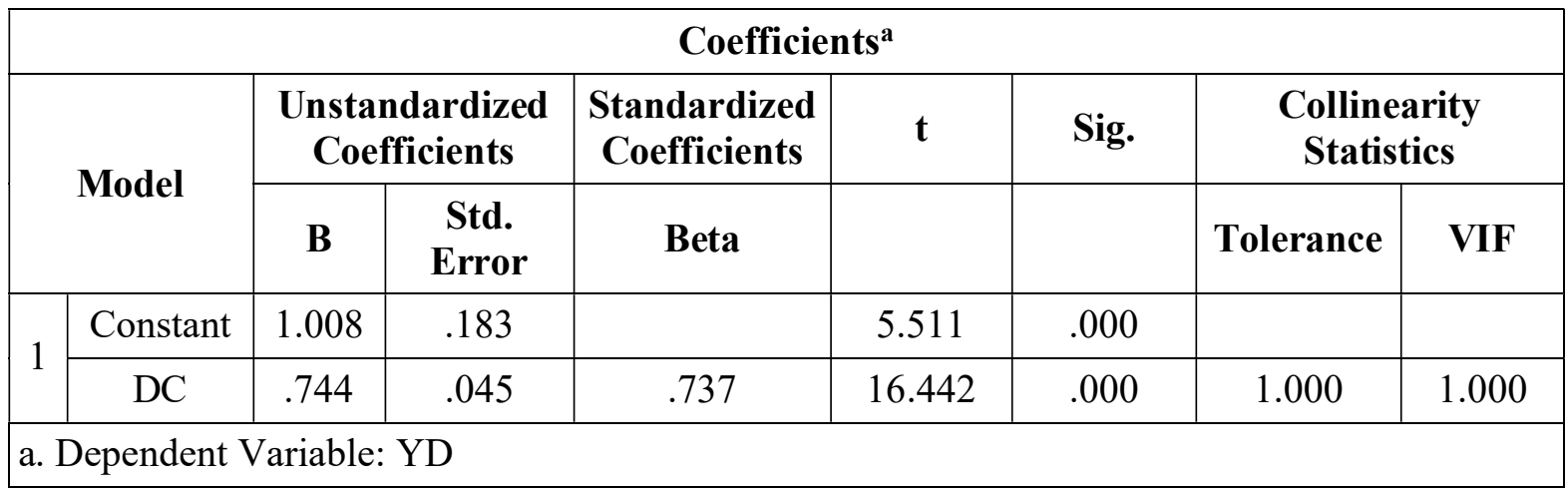

Source: Data analysis result of the research

We have a linear regression equation for an independent variable as follows:

$$
\mathrm{YD}=1,008+0,744 \mathrm{DC}
$$

The adjusted model is shown in Figure 2.

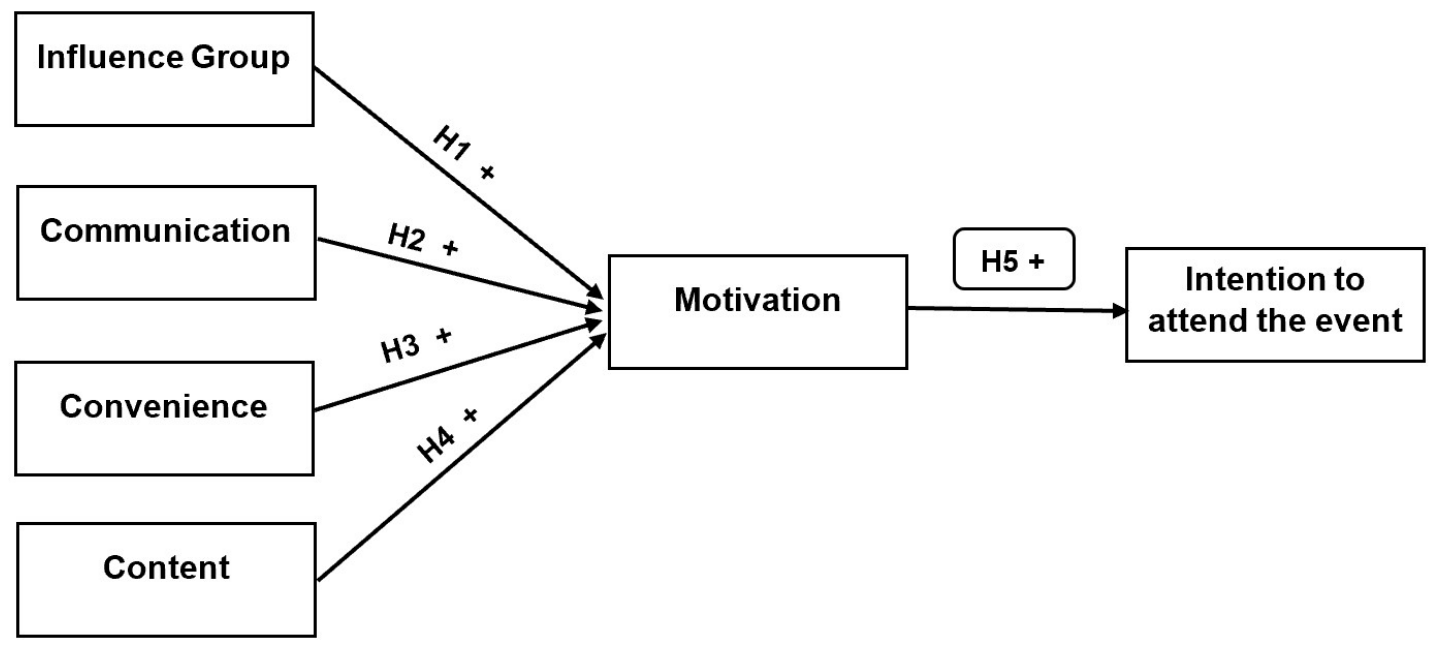

Figure 2. The adjusted model

The motivation to participate in a tourism event positively affects the intention to attend that event. The results of the regression analysis show that coefficient Beta $=0.744$ and $p=0.000$, so hypothesis H5 is accepted. This shows that the higher the motivation is, the more a customer intends to participate in a tourism event.

Influence groups, communications, convenience, and content positively affect the motivation to participate. An overall review of the average results of the independent and dependent variables from Table 3 shows that the majority of responses are at the agreement level 
or above. In particular, the average of the influence group, communication, and content is nearly equal and at a fairly good level. Convenience has the highest average.

The motivation positively impacting customers' intention to participate in the event is proven by Beta coefficient of 0.744 . From there, we can conclude that the variables having a positive impact on motivation such as influence group, communication, content, and convenience also positively affect the intention to participate in tourism events.

\section{Conclusion and recommendations}

\subsection{Conclusion}

The study results show that from the initial model, 7 factors are affecting the intention to participate in tourism events with 24 observed variables. After the authors do the research, investigation, survey, and model running, there are 4 remaining factors influencing the motivation to attract customers to the event and thereby their intention to attend. These 4 factors include influence group, communication, convenience, and content of the event. When making a comparison with previous studies, we can see that there is a change in the factors affecting the motivation to attract customers to tourism events. Factors of time, weather, and location do not affect the intention to participate in an event. On the other hand, the content, communication, and convenience factors greatly influence the motivation to attract customers to the event. This level of influence is also different from that of previous studies in the oversea countries due to the specific context of Vietnam. The results also indicate that the higher the motivation is, the higher the intention to attend the tourism event will be.

\subsection{Recommendations}

From the above analysis data, the authors suggest some recommendations to help increase the attraction of customers participating in tourism events:

First: Focus on the content of the tourism event. Content is the soul that makes a successful event. There should be a need for specific content with a humane meaning to attract customers. Tourism events can create content such as promoting images and products of the homeland to help Vietnam reach out to the world, or taking a news factor or a hot trend as content to help increase customer attraction to the event.

Second: Promote communication in the mass media. Tourism events should be widely promoted on media channels such as newspapers, internet, television, billboards, etc. Specifically, they should be integrated into the current news such as announcing the starting and ending date and time of certain tourism events.

Third: Increase the convenience in tourism events. The authors propose to increase the number of seats for guests to take a rest after visiting a tourism event, to arrange public toilets for visitors as well as to create a parking space largely enough and near the event venue, thereby making it convenient for visiting as well as for personal privacy.

\section{References}

Alderfer, C. P. (1969). An empirical test of a new theory of human needs. Organizational Behavior and Human Performance, 4(2), 142-175. doi:10.1016/0030-5073(69)90004-X 
Anderson, J. C., \& Gerbing, D. W. (1988). Structural equation modeling in practice: A review and recommended two-step approach. Psychological Bulletin, 103(1), 411-423. doi:10.1037/0033-2909.103.3.411

Aziz, A. (2002). An evaluation of the attractiveness of langkawi island as a domestic tourist destination based on the importance and perceptions of different types of attractions (Doctoral Dissertation, Michigan State University). Retrieved February 11, 2020, from https://d.lib.msu.edu/etd/31817

Ban Chuyên đề. (2019). 10 sự kiện văn hóa, thể thao, du lịch nổi bật năm 2019 [10 outstanding cultural, sports and travel events in 2019]. Retrieved February 12, 2020, from Communist Party of Vietnam Online Newspaper website: http://dangcongsan.vn/thoi-su/10-su-kienvan-hoa-the-thao-du-lich-noi-bat-nam-2019-545741.html

Bauer, T., Law, R., Tse, T., \& Weber, K. (2008). Motivation and satisfaction of mega-business event attendees: The case of ITU Telecom World 2006 in Hong Kong. International Journal of Contemporary Hospitality Management, 20(2), 228-234. doi:10.1108/09596110810852195

Bennett, P. D. (1988). Marketing (The McGraw-Hill series in marketing). New York, NY: McGraw-Hill.

Brown, M. W., \& Cudeck, R. (1993). Alternative ways of assessing model fit. In K. A. Bollen \& J. S. Long (Eds.), Testing structural equation models (pp. 136-162). Newbury Park, CA: Sage.

Bui, T. T., \& Mai, Q. L. (2012). Assessing the ability to attract tourists to Hue destination. Hue University Journal of Science, 72b(3), 295-305.

Crompton, J. L., \& McKay, S. L. (1997). Motives of visitors attending festival events. Annals of Tourism Research, 24(2), 425-439. doi:10.1016/S0160-7383(97)80010-2

Crouse, A. J. (2013). Factors affecting student decisions to attend selected BGSU athletics events. Honors Projects, Ohio: Green State University.

Denaux, Z. S., Denaux, D. A., \& Yalcin, Y. (2011). Factors affecting attendance of major league baseball: Revisited. Atlantic Economic Journal, 39(2), 117-127. doi:10.1007/s11293-011-9274-2

Hair, J. F., Anderson, P. E., Tatham, R. L., \& Black, W. C. (1998). Multivariate data analysis. Upper Saddle River, NJ: Prentice Hall.

Hu Truc (2019). Những sự kiện văn hóa, du lịch nổi bật năm 2019 [Outstanding cultural and tourism events in 2019]. Du Lich Vietnam Online. Retrieved February 11, 2020, from https://dulichvietnam.com.vn/nhung-su-kien-van-hoa-du-lich-noi-bat-nam-2019.html

Hudson, M. (2010). Factors that influence Cal Poly students' decision to attend sporting events and theatrical performances. Retrieved February 13, 2020, from https://digitalcommons.calpoly.edu/cgi/viewcontent.cgi?article $=1004 \&$ context $=$ rptasp

Kim, W., \& Malek, K. (2017). Understanding the relationship among motivation to attend, satisfaction, and loyalty of medical convention attendees. Journal of Convention \& Event Tourism, 18(4), 282-300. doi:10.1080/15470148.2017.1366384

Kotler, P., Bowen, J. T., Makens, J., \& Baloglu, S. (2016). Marketing for hospitality and tourism. Upper Saddle River, NJ: Pearson. 
Le, A. T. N., \& Tran, K. T. (2014). Đánh giá khả năng thu hút khách du lịch của điểm di tích Đại Nội - Huế [Assessing the capability of attracting tourists of Hue Royal Citadel]. The Magazine for Research and Development, 1(108), 22-29.

Maslow, A. H. (1943). A theory of human motivation. Psychological Review, 50(4), 370-396.

Martensen, A., \& Grønholdt, L. (2008). How events work: Understanding consumer responses to event marketing. Innovative Marketing, 4(4), 44-56.

McClelland, D. C., Atkinson, J. W., Clark, R. A., \& Lowell, E. L. (1953). The achievement motive. New York, NY: Appleton-Century-Crofts, Inc.

McClelland, D. C., \& Winter, D. G. (1969). Motivating economic achievement. New York, NY: Free Press.

Michael, R. S. (2017). Consumer behavior: Buying, having, and being. Upper Saddle River, NJ: Pearson.

Nguyen, N. T. M., Tran, T. H., \& Le, N. V. T. (2017). Factors affecting the attraction of domestic tourism to Hoi An. Hue University Journal of Science, 126(5D), 29-39.

Nohria, N., Groysberg, B., \& Lee, L. E. (2008). Employee motivation: A powerful new model. Harvard Business Review, 78(7/8), 78-84.

Pearce, D. G., \& Nicholson, R. E. (2001). Why do people attend events: A comparative analysis of visitor motivations at four South Island events. Journal of Travel Research, 39(4), 449460. doi:10.1177/004728750103900412

Phuong Anh (2019). Tìm hương đi mói cho ngành du lịch Việt Nam [Finding new directions for Vietnam 's tourism industry]. Retrieved January 11, 2020, from Báo Ảnh Dân Tộc và Miền Núi website: https://dantocmiennui.vn/du-lich/tim-huong-di-moi-cho-nganh-du-lich-vietnam/281181.html

Stastictics (2019a). Stastictics of international tourist to Vietnam. Retrieved January 12, 2020, from $\mathrm{http}$ //vietnamtourism.gov.vn/index.php/statistic/international?txtkey=\&year=2019\&period=t12

Stastictics (2019b). Stastictics of domestic tourist in 2000-2018. Retrieved January 13, 2020, from $\mathrm{http}: / /$ vietnamtourism.gov.vn/index.php/statistic/international?txtkey=\&year=2019\&period=t12

Thompson, K. J., \& Schofield, P. (2009). Segmenting and profiling visitor to the Ulaanbaatar Naadam Festival by motivation. Event Management, 13(1), 1-15. doi:10.3727/152599509789130601

Thu Thuy (2019). Giải pháp phát triển du lịch gắn với các sụ kiện thể thao tại Việt Nam [Solutions for developing tourism associated with sporting events in Vietnam]. Retrieved January 14, 2020, from http://vietnamtourism.gov.vn/index.php/items/30277

Truyen Phuong (2019). Án tuợng tăng trương Du lịch Việt Nam trong bối cảnh khó khăn chung của thế giới và khu vục [Impressive growth of Vietnam's tourism in the context of common difficulties of the world and the region]. Retrieved January 15, 2020, from http://vietnamtourism.gov.vn/index.php/items/30873

Vengesayi, S., Mavondo, F., \& Reisinger, Y. (2013). Tourism destination competitiveness: The impact of destination resources, support services and human factors. Journal of Tourism, 14(1), 79-108. 